\title{
Editorial: TUO YAW
}

The London Transport Executive does not sell much advertising space to philosophical enterprises, but for a good many years now there has been a vigorous campaign on the Underground stations in support of evening courses in PHILOSOPHY held during the winter months. These are not the series of lectures put on by the Royal Institute of Philosophy at Gordon Square, even though the typography of the title is at least very close to that of the same word printed on the front cover of this journal. They are provided by an institution called the School of Economic Science, which accordingly also offers courses on ECONOMics. Some of the arrangements detailed in the smaller print suggest a fairly prosperous provider and a substantial following of students. Each lecture is given on five successive evenings, so that students whose other engagements require them to stagger their pursuit of philosophic wisdom or economic knowledge can nevertheless be sure of continuity and completeness in their courses.

London newspapers have not often taken much interest in philosophical lectures or societies. Even The Times, which regularly publishes accounts of the proceedings of the Classical Association and of the Triennial Joint Meetings of the Greek and Roman Societies, forbears to notice the Annual Joint Sessions of the Mind Association and the Aristotelian Society. But the SES has at various times attracted attention from the Daily Mail, the Standard and the News of the World, as well as from newspapers in Ireland, New Zealand, Holland and Belgium. There is now a book called Secret Cult, written by Peter Hounam and Andrew Hogg and published by Lion Paperbacks at $£ 1.95$, in which the Standard's investigators offer 'A full exposé of a strange and destructive organization that is penetrating the corridors of power'.

Secrecy and entryism into the corridors of power are not the only crimes against the liberal creed of the investigative journalist that are alleged by those who arraign the SES. The School is also charged with indoctrination of the young through its two private schools, and with breaking up marriages, and alienating children from their parents, by its remorseless pressure on those who once take up its tenets.

Yet the political party with which the School has the closest association is the Liberal Party. Messrs Hounam and Hogg print as an appendix a long letter from Mr Roger Pincham, who at the time of writing was Chairman of the Liberal Party: 'As a Liberal I value every positive aspect of freedom which includes freedom to assemble, freedom to 
worship, freedom of reasonable privacy, the freedom to teach and the freedom to learn, the freedom to seek excellence and the freedom to aspire to virtue'. The critics wonder how he can reconcile these ideals with his support of 'a strange, eccentric, essentially Eastern cult'.

None of those adjectives severally or collectively can be said to amount to a proof of illiberalism, even against defendants whose offences include whole-food faddism, the introduction (surely the belated reintroduction?) of elementary Sanskrit into the curriculum of independent schools, and a determination to increase the proportion of the educated population who not only know how to spell Gurdjieff's name but are actually interested in his thought.

The prosecution raises more serious points when it presents case histories of disaffected ex-students of the School, whose complaints are like those made against other cults that have been loved and hated by popular newspapers. The interest of much of the material goes beyond the level of newsworthiness into matters of philosophical and political principle about the rights of parents over their children's minds, and wider questions of the toleration of minority convictions and pursuits which may appear to the majority to threaten the public interest. The debate will continue, and not only in the popular prints.

What at first appeared to be an equally alarming threat was a false alarm. In many public places, including Underground stations, there occurs again and again the alien and somewhat menacing inscription TUO YAW, which might seem to be the slogan of 'a strange, eccentric, essentially Eastern cult'. Travellers are advised to follow Wittgenstein's method, and to rotate the axis of reference of their examination about the fixed point of their real need. Every fly-bottle has a way out, even if the notice that points to it is sometimes seen through a reflecting surface, strangely, eccentrically, orientally. 